\title{
Volunteer now
}

\section{Get involved with ACRL by serving on a division or section committee}

A CRL volunteers are an integral part of the association who help shape the organization by advancing its strategic plan and influencing the direction of academic and research librarianship. Volunteering to work on a committee is one of the best ways to be involved and make an impact with your association.

If you have been looking for a way to become more involved, ACRL Vice-President/ President-Elect Joyce Ogburn invites you to volunteer for a division or section committee for the 2011-12 term.

\section{The rewards of volunteering}

Volunteers benefit by:

- building ties with academic and research librarians around the country,

- enhancing their leadership abilities through consensus building and project management,

- sharing their experience with colleagues,

- gaining additional expertise about a new area of academic librarianship or updating expertise in a current specialization, and

- advancing the work of the association and the profession.

\section{The appointment process}

Appointments are made at the division and section level. The ACRL vice-president is responsible for committee appointments at the division level for the year he or she serves as president. The ACRL Appointments Committee assists the vice-president in an advisory capacity. Section vice-chairs are responsible for committee appointments for the year they will serve as chair. Most committee appointment offers will be sent in April and May 2010.

\section{Factors influencing appointment}

Although the emphasis in the appointment process may vary from year to year according to the priorities of the vice-president/ president-elect and section vice-chairs, several factors are always considered:

- Evidence of prospective committee member's interest and expertise. Have potential volunteers attended the meetings and introduced themselves to the chair? Do they have knowledge and/or previous experience that relates to the work of the committee? Have they indicated their interest on the volunteer form?

- Demographics and composition of committee. A balance is sought with respect to type of library (community college, college, or university), geographic representation, ethnic diversity, and gender. Those who have not had the opportunity to serve on an ACRL committee are encouraged to volunteer.

- Recommendation of the current committee chair. Current committee chairs are asked to suggest prospective members.

The final appointments are the prerogative of the ACRL president-elect and the section vice-chairs.

\section{How to apply}

1. Identify the committees that interest you. ACRL committees and their charges are listed on the ACRL Web site (www.acrl.org, select "Directory of Leadership" from the menu bar). Attend committee meetings at the ALA Midwinter Meeting and Annual Conference to help you decide if their activities interest you. Talk with committee members. Express your interest to the committee chair. Ask about current projects and explain how you might contribute to the work of the committee. 
2. Submit a volunteer form. For division-level committees, visit www.ala.org/ala /mgrps/divs/acrl/resources/forms/volunteer.cfm for more detailed instructions. Volunteer forms should be submitted by February 15, 2011.

For section committees, complete the online volunteer form at www.acrl.org /volunteer. You will be asked to login using your ALA member ID and the password you created. The form should be completed by February 15, 2011.

3. Volunteer again. If you are not successful in being appointed one year, volunteer again the next year.

Remember that many factors-number of appointments made, number of volunteers for each committee, number of volunteers from your type of library or your geographic areadetermine the actual appointment, and these factors change from year to year.

\section{ACRL division-level committee appointments}

ACRL has more than 50 standing committees for which you may volunteer to serve for 2011-12. The committees are listed along with their charges on the ACRL Web site (www.acrl. org, select "Directory of Leadership" from the menu bar).
Appointments to ACRL standing committees are made in the spring for terms beginning immediately after the ALA Annual Conference. The Appointments Committee recommends to the president-elect of ACRL the names of members who might fill the vacancies. The president-elect makes the final appointments for the committees.

Questions about division-level appointments may be directed to the Chair of the Appointments Committee, Lisa B. German, Pennsylvania State University; e-mail: 1bg10@ psu.edu.

If you have any questions about using the volunteer form, please contact ACRL Program Officer Adam Burling at aburling@ala.org or (312) 280-2521.

\section{ACRL section appointments}

ACRL has 17 sections to help members customize their ACRL experience through newsletters, electronic discussion lists, specialized programming, preconferences, recognition, and focused activities. A description of their areas of responsibility is available at www. ala.org/ala/mgrps/divs/acrl/about/sections /index.cfm.

Section vice-chairs appoint the members of section committees. Most of these ap-

\section{Nominations sought for ACRL vice-president/president-elect}

"When nothing is sure, everything is possible."-Margaret Drabble

Higher education is experiencing unprecedented change, providing academic libraries with tremendous opportunities to define new roles related to learning, teaching, and research.

ACRL is dedicated to enhancing the ability of library and information professionals to dream big and shape our new future.

Be a part of shaping that future. The ACRL Leadership Recruitment and Nominations Committee encourages members to nominate themselves or others to run for the position of ACRL vice-president/ president-elect in the 2011 elections.

To nominate an individual or to self-nominate, send the nominee's name and institution to: Karen Williams, University of Minnesota; phone:(612)626-4190;e-mail:kaw@umn.edu.

Once nominated, individuals will need to submit a two-page curriculum vita or resume (if self-nominating, you may include these materials with your nomination).

The Leadership Recruitment and Nominations Committee will request statements of interest from selected individuals prior to developing a slate of candidates.

The deadline for nominations is November 20, 2010. 
pointments are made in the spring for terms beginning immediately after the ALA Annual Conference.

If you would like to be considered for appointment as a chair or member of a section committee, fill out the ACRL volunteer form at www.acrl.org/volunteer by February 15, 2011. If you have questions about the form, please contact ACRL Program Officer Adam Burling at aburling@ala.org or 312-280-2521. Contact information for the vice-chair of each section is below.

\section{African American Studies Librarians} Section. Rebecca Hankins, Texas A\&M; phone: (979) 845-1951; e-mail: rhankins@ library.tamu.edu.

\section{Anthropology and Sociology Section.} Terrence W. Epperson, College of New Jersey; phone: (609) 771-3352; e-mail: epperson@ tcnj.edu.

Arts Section. Megan Smith-Heafy, Corning Museum of Glass; phone: (607) 368-3721; e-mail: smithheafy@gmail.com.

\section{Asian, African and Middle Eastern} Section. Binh P. Le, Pennsylvania State University; phone: (215) 881-7426; e-mail: bpl1@psu.edu.

College Libraries Section. Celia E. Rabinowitz, Saint Mary's College of Maryland; phone: (240) 895-4267; e-mail: cerabinowitz@ smcm.edu.

\section{Community and Junior College Librar-} ies Section. Nan Schichtel, Grand Rapids Community College; phone: (616) 234-3082; e-mail: schichteln@comcast.net.

Distance Learning Section. Samantha Hines, University of Montana-Missoula; phone: (406) 243-4558; e-mail: samantha. hines@umontana.edu.

\section{Education and Behavioral Sciences}

Section. Sally R. Neal, Butler University; phone: (317) 940-9949; e-mail: sneal@butler. edu.

Instruction Section. Stephanie A. Michel, University of Portland; phone: (503) 943-7418; e-mail: michel@up.edu.

Law and Political Science Section. Chad M. Kahl, Illinois State University; phone: (309) 438-3454; e-mail: cmkahl@ilstu.edu.

Literatures in English Section. Faye Christenberry, University of Washington-Seattle; phone: (206) 616-2758; e-mail: fayec@u. washington.edu.

Rare Books and Manuscripts Section. Mike Kelly, Amherst College; phone: (413) 542-5307; e-mail: mkelly@amherst.edu.

Science and Technology Section. Mary Beth Slebodnik, Purdue University; phone: (765) 494-2917; e-mail: slebodnik@purdue.edu.

Slavic and East European Section. Liladhar Ramchandra Pendse, UCLA Department of Information Studies; phone: (310) 825-1639; e-mail: lpendse@library.ucla.edu.

University Libraries Section. Carol Hixson, University of South Florida-St. Petersburg; phone: (727) 873-4400; e-mail: hixson@ mail.usf.edu.

Western European Studies Section. Gail P. Hueting, University of Illinois-Urbana; phone: (217) 244-0481; e-mail: ghueting@ illinois.edu.

Women's Studies Section. Pamela Mann, St. Mary's College of Maryland; phone: (240) 895-4285; e-mail: pemann@smcm.edu.

\section{Editorial boards}

ACRL has eight editorial/advisory boards for its publications: Academic Library Trends and Statistics Survey Editorial Board; Choice Editorial Board; College $\&$ Research Libraries Editorial Board; Col- 
lege \& Research Libraries News Editorial Board; New Publications Advisory Board; Publications in Librarianship Editorial Board; RBM: A Journal of Rare Books, Manuscripts, and Cultural Heritage Editorial Board; and Resources for College Libraries Editorial Board.

Appointments to editorial boards are made after the ALA Midwinter Meeting for terms that begin immediately after the ALA Annual Conference. The editors recommend the names of individuals to fill vacancies. The Publications Coordinating Committee approves the recommendation and the ACRL vice-president/ president-elect makes the appointment.

If you would like to be considered for appointment to an editorial board, contact the editor of the editorial board early in the fall or indicate your interest on the ACRL online volunteer form.

Academic Library Trends and Statistics Survey Editorial Board chair: William Miller, Florida Atlantic University; e-mail: miller@fau.edu.
CHOICE editor: Irving Rockwood, Choice; phone: (800) 347-6933 x119; e-mail: irockwood@ala-choice.org.

College \& Research Libraries editor: Joseph Branin, King Abdullah University of Science and Technology; e-mail: joseph. branin@kaust.edu.sa.

College \& Research Libraries News editor: David Free, ACRL; phone: (312) 2802517; e-mail: dfree@ala.org.

New Publications Advisory Board staff liaison: Kathryn Deiss, ACRL; phone: (312) 280-2529; e-mail: kdeiss@ala.org.

Publications in Librarianship editor: Craig Gibson, George Mason University; phone: (703) 993-3716; e-mail: jgibson1@ gmu.edu.

RBM: AJournal of Rare Books, Manuscripts, and Cultural Heritage editor: Beth Whittaker, Ohio State University; phone: (614) 247-7463; e-mail: whittaker.50@osu.edu.

Resources for College Libraries chair: Brian Coutts, Western Kentucky University; phone: (270) 745-6121; e-mail: Brian.Coutts@ wku.edu. $n$

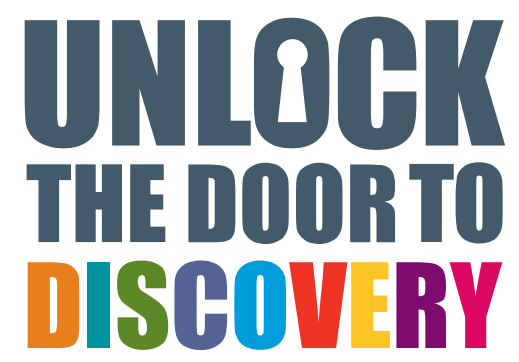

Project MUSE now offers you more rich archival content online. Back issues from nearly 100 of our respected, peer-reviewed journals are being added, and complete runs - from Volume I, Issue I — are now available for over 60 titles.

A core discovery and research tool for faculty and students in the humanities and social sciences since I995, MUSE makes

access affordable and easy. Our tiered pricing and six collection options offer unbeatable value and can satisfy any library's needs and budget. With Project MUSE, you get:

- 24/7 access to full text current and archival content from core journals

- new, easy to use search and browsing tools

- stable online content with archival rights

So open the door to the past, and find future inspiration. Discover more at http://muse.jhu.edu

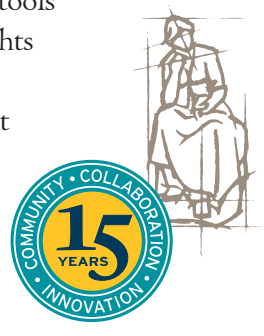

Project

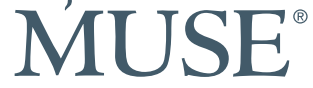

Today's Research.

Tomorrow's Inspiration.

FREE 45-day trial offer muse.jhu.edu/trialrequest 